\title{
Gully Erosion and Its Environmental Impact in Eke, Udi Local Government Area of Enugu State
}

\author{
Okwu-Delunzu V. U. ${ }^{1, *}$, Iwueke, N. T ${ }^{1}$, Aniagolu C. O. ${ }^{2}$ \\ ${ }^{1}$ Department of Geography \& Meteorology, Enugu State University of Science and Technology, Nigeria \\ ${ }^{2}$ Department of Estate Management, Enugu State University of Science and Technology, Nigeria
}

Copyright $\mathrm{C} 2018$ by authors, all rights reserved. Authors agree that this article remains permanently open access under the terms of the Creative Commons Attribution License 4.0 International License

\begin{abstract}
This paper assessed the environmental impact of gully erosion in Eke, Udi Local Government Area of Enugu State, South East Nigeria. Data on the gully sites were collected using measuring instrument; observations were made with regards to the effects of the hazard on the study areas. Simple random sampling techniques were used to select respondents. A total of 150 questionnaires were returned out of 200 questionnaires distributed. Findings show that the gully in Enugu Eke has a mean cross-sectional dimension of $15.67 \pm 14.01 \mathrm{~m}$, that of Oma Eke $13.00 \pm 12.49 \mathrm{~m}$, while Ogui Eke has a mean cross-sectional dimension of $7.60 \pm 5.70 \mathrm{~m}$. From the mean values, differences was observed among the various study sites, however, with very high standard deviations and standard errors for Enugu Eke and Oma Eke, supported by the ANOVA results, having calculated F-value of 0.395 , which is less than the critical F-value of 5.14, and the p-value of $0.69>0.05$. The difference observed among the three study sites is not significant. Hence, the null hypothesis is accepted. The study revealed that the initiation and development of erosion gullies in the area is facilitated by natural (rainfall, topography, engineering geological properties of soil especially texture, etc) and anthropogenic factors especially road construction, excavation, drainage structure, farming, animal grazing. The study observed that gully erosion have caused a lot of pain and damage such as loss of life's, properties, communication routes, roads and has also modified the topography of the area. Recommendation made include planting of vegetative cover, construction of erosion channels, educating the populace and creating awareness on adequate practices to curtail the menace.
\end{abstract}

Keywords Gully Erosion, Environmental Impact, ANOVA, Topography, Eke

\section{Introduction}

Soil erosion is a geomorphic process whereby the surface layer of weathered rock is loosened and carried away by wind, running water, wave, ice and a lower horizon in the soil or rock is exposed (Morgan [1].) Ordinarily, soil erosion when balanced with soil formation is said to be normal when it occurs as a natural process. However, erosion becomes a serious issue when it is accelerated (Ofomata, [2].) The term "accelerated" is often used when the removal of soil is far faster than its replacement or the natural way by which the soil is formed. Thus accelerated erosion is defined as the displacement and removal of soil from a land surface such that the removal process far exceeds its replacement by pedological process (Strahler, [3].) According to Strahler [3], the area of the world estimated to be suffering from some form of land degradation stands at about 2 billon hectares. In this regard, fluvial erosion affects about $56 \%$ of the degraded land and thereby making it a major factor contributing to the process of land degradation.

Soil erosion has been recognized not only in the rural areas but also in urban environments for several years in Nigeria and in many other parts of the world (Siakeu and Oguchi.[4]). The greatest threat to the environmental setting of Southeastern Nigeria is the gradual but constant dissection of the landscape by soil erosion (Ofomata, [5]).Soil erosion through rill and inter rill are common and easily managed by the people through recommended soil conservation practices, the gullies formed have assumed a different dimension such that settlements and scarce arable land are threatened. Therefore, gully erosion problems have become a subject of discussion among soil scientists, geographers, geologists, engineers and social scientists. Ofomata [5] indicated that gully erosion types are the most visible forms of erosion in Nigeria mainly because of the remarkable impression they leave on the surface of the earth. He also noted that more than $1.6 \%$ of the entire land area of eastern Nigeria is occupied by gullies. This is very significant for an area that has the highest population density of 500 persons per $\mathrm{km}^{2}$ in Nigeria. Before the 1980 s, the classical gully sites in the region were the Agulu, Nanka, Ozuitem, Oko in Aguata area, Isuikwuato and Orlu. With increasing developmental activities the number and the magnitude have escalated (Ajaero and Mozie [6]), For this making many Government administration within the region to set up soil erosion agencies with different names 
in different states showing interest in ecological problems in the country, including the control of the gullies which has reached more than 600 active sites in the region (Enugu State Ministry of Environment Field Survey,[7]). Ever since then there has been a constant enquiry as to the causes of erosion menace. Most researches have shown that the environmental factors of vegetation, geology, geomorphology, and climate in the form of rainfall which is very aggressive in the region and the soil factor contribute to the erosion problem and their development (Ofomata [5], Igwe [8]). The consequences of soil erosion include loss of land for agriculture and habitation (Okwu-Delunzu V.U et al [9]). Serve soil erosion has led to some landslides, loss of lives while some communities have been separated because of deep and very wide gullies that in some cases are up to $12 \mathrm{~m}$ deep and more than $1.5 \mathrm{~km}$ long like Nanka/Agulu gully complexes or in Oko in Aguata, Anambra state (Igbokwe, Akinyede, Dang, Alaga, Ono, Nnodu and Anike [10]). Crop yields have been reduced, thus creating problem of food scarcity and poverty in the areas. In Agbadala Achi in Oji River Local Government Area of Enugu State in 2008, many households and road were cut off by gully erosion in the area (Okwu-Delunzu,[11]). In Eke, gully erosion have caused physical damage to structures, social dislocation, contamination of clean drinking water, damage of farm land, death of non-tolerant tree species, disruption in transportation system and serious economic loss. Government also had employed different construction companies at the various erosion sites to stop the gullies from further development. Individuals have contributed in their own way by cultivating grasses on the erosion prone areas. They also dump their refuse in the gullies in order to cover up the gullies and prevent further erosion. But gully erosion in Eke area however has not been completely eradicated. Thus soil erosion as an environmental hazard has attracted the attention of many researchers and government organizations. The knowledge of the different gully erosion parameters which include the gully erosion duration, the width, the depth, and the height of various gully incidences are issued investigated in this study in order to assess the environmental impact of gully erosion. This investigation has the aim for the study the environmental impact of Eke gully areas (Enugu Eke, Oma Eke and Ogui Eke communities) and to find out the principal causes of the menace, and its effect on the community."

\section{Materials and Methods}

\subsection{The Study Area}

The study area- Eke, which of Enugu Eke, Oma Eke, Ogui Eke, Amofia Eke and Amankwo Eke communities located in Udi Local Government Area of Enugu State, South Eastern Nigeria. It shares borders with Kogi State by the North, Ebonyi State by the East, Abia State by the South and Anambra State by the West.(Figure 1 and 2).

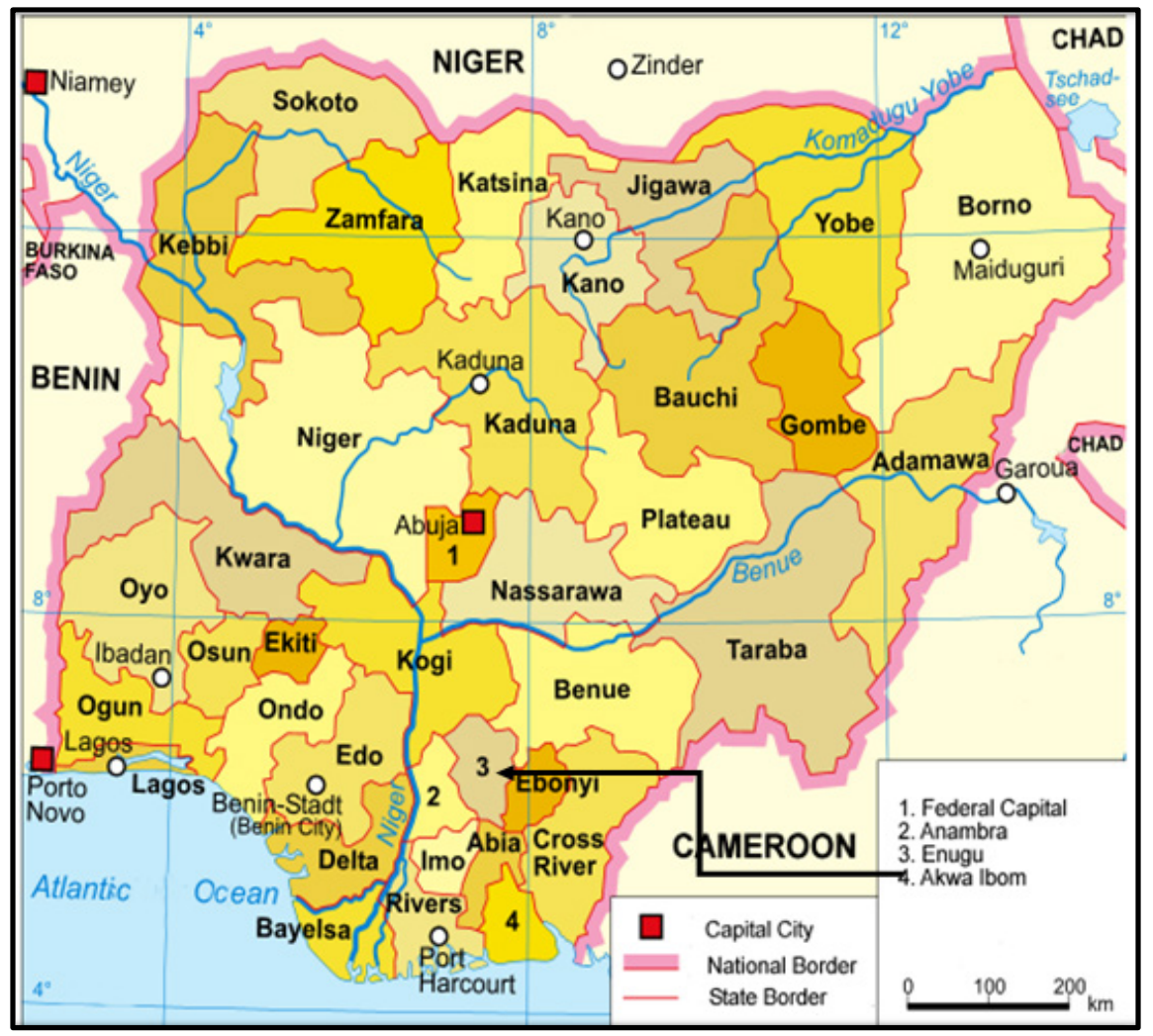

Source: Global Map.Com, (2014).

Figure 1. Map of Nigeria with Enugu State 


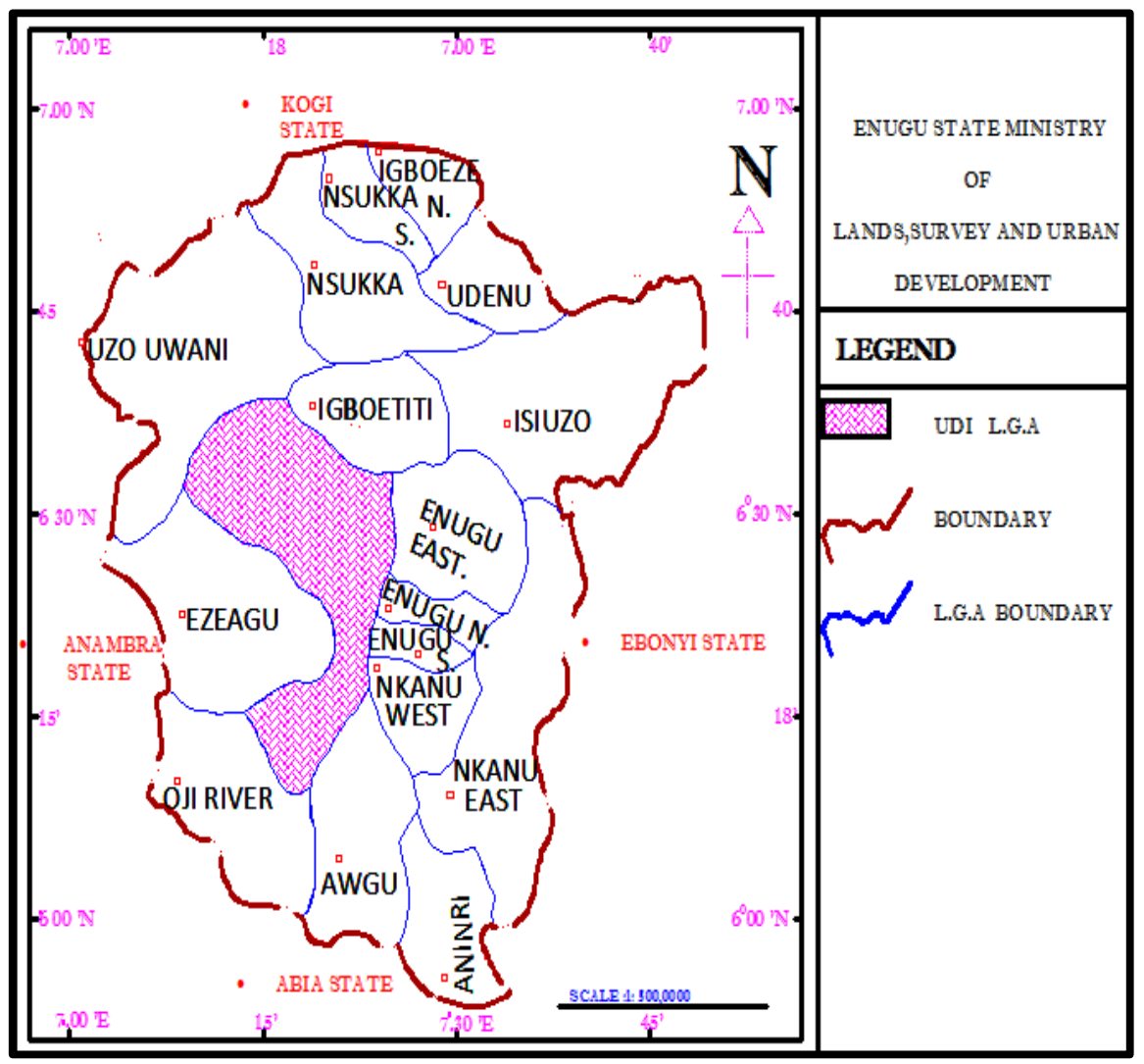

Figure 2. Map of Enugu State with Udi L.G.A

Eke is one of the most prominent of the twenty-five communities in Udi Local Government Area of Enugu State. It is located on longitude $6^{\circ} 19^{\prime} \mathrm{N}$ and latitude $7^{\circ} 26^{\prime} \mathrm{E}$ (Figure 2). Eke lies about 16km west of Enugu and only $5 \mathrm{~km}$ from the strategic $9^{\text {th }}$ mile corner which links the town with Enugu and Onitsha, Nsukka and parts of northern Nigeria. Eke is bordered on the east by Ngwo, on the west by Aguobu Owa, North by Ebe and South by Nsude communities. (Figure 3) (Ofomata, [5]).

The population of Eke is about 28,836 (NPC, [12]). The native population is of Igbo ethnicity. The growth rate of Eke has been projected from the year 2006 to 2013 with the estimate of 35,055 people.
Eke sits at 223meters (732ft) above sea level, endowed with the Udi, Awgu and Nsukka highlands and with well-drained soil during its rainy seasons. Eke occupies much of the highland of Udi. The hills are flanked by rolling low land to the Oji River basin. Highlands surrounding Eke for the most part and low lands are underlain by shale. Much of the escarpment stretching from Eke to Udi has been ravaged by soil and gully Erosion. The Eke soil is made up of shallow and stony lithosols found the steep slope of the cuesta and often left uncultivated. The ferrallitic soil also called red earth or acid sands, found on the plateau and the hydromophic soil of the flood plains. 


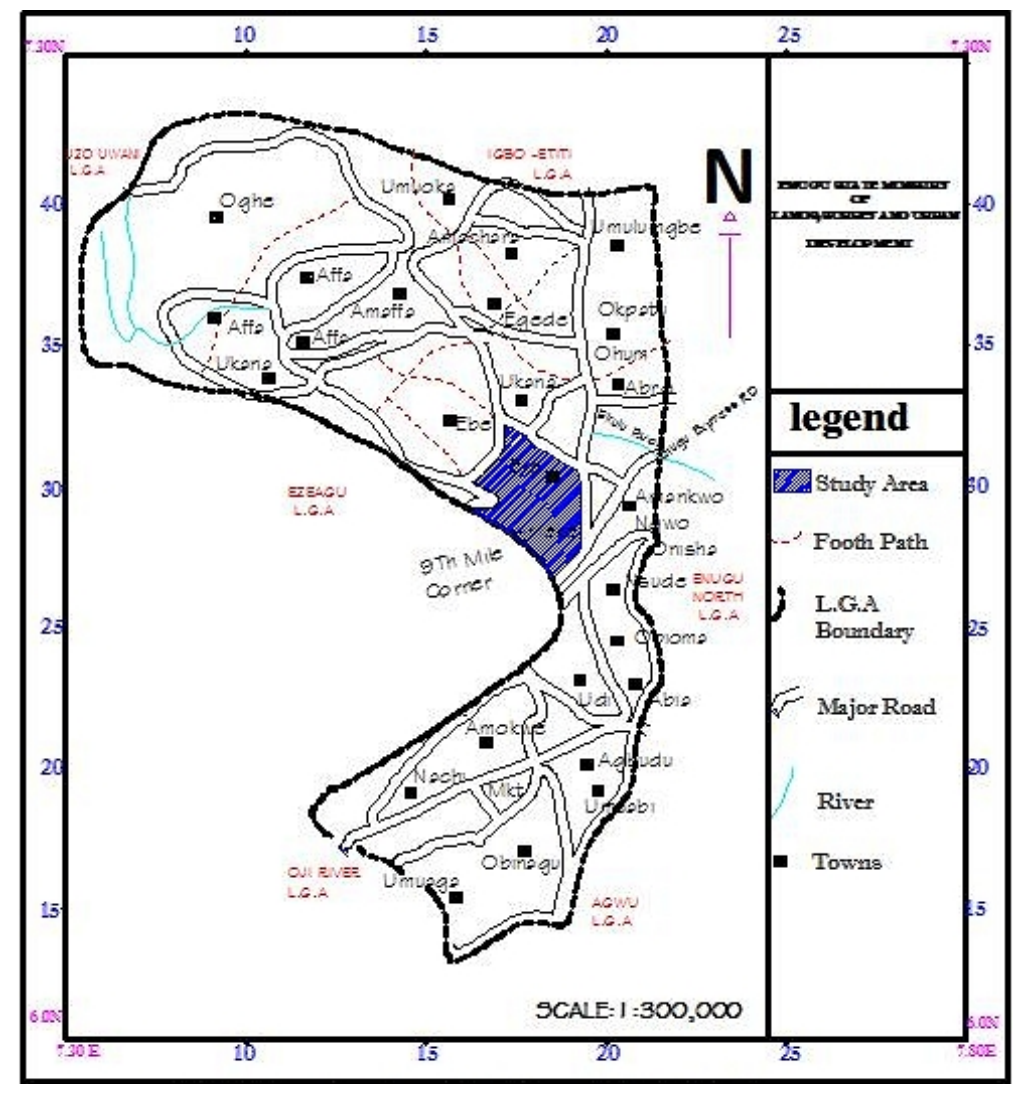

Figure 3. Locational Map of Udi L. G. A. with Eke

Eke have tropical wet and dry climate. The annual rainfall amount ranges between $859 \mathrm{~mm}-1839 \mathrm{~mm}$. The climate is generally cold during the raining season which lasts from March to October and relatively hot during the dry season. The dry season commences in November and lasts till April. Average temperature is $28^{\mathrm{oC}}$. December and early January are coldest as a result of dry dusty harmattan winds. (NIMET.[13]). Eke have derived guinea savannah vegetation. The highlands are of semi-tropical rain forest type. It is characteristically green and is complemented by typical grassy vegetation. Fresh water swamp forests occur in Udi. (Mozie,[14]). Eke is close to the $9^{\text {th }}$ mile corner and is blessed with a natural aquifer which is very close to the surface of the earth. So the area serves as a good source of potable water which has attracted many industries like Aqua Rapha Company, Amah Brewery (the largest brewery in West Africa) and the major soft drink bottling companies of Coca cola, Limca and seven up company. The area is predominantly involved in farming and trading activities.

\section{Research Methods}

The population for the study constitutes the people of Eke in Udi Local Government Area with an estimated population of 28,836 persons (NPC,[13]). The survey research method was employed, using sampling technique, three villages were selected to represent Eke community they are Enugu Eke, Oma Eke and Ogui Eke. For primary data, measurement, photograph and questionnaires were sourced from the field work and secondary data from the library, text books and related work on gully erosion. Structured questionnaires were physically distributed to the respondents in Eke and their responses were used to assess the effect of gully erosion in Eke, measures they take for the controls. A total of 200 copies of questionnaires were administered, 150 of them were properly filled and returned. Information was also collected using measuring equipment (tape, pole) to collect data at gully sites. Observations were made with regards to the effects of the hazard on the study areas.

The cross-sectional area of each of the gullies studied was determined using a formula adopted from Ofomata, [5] for south eastern Nigeria. The formula is given as:

$$
\mathrm{A}=\mathrm{WD}
$$

Where A $=$ cross-sectional area $\left(\mathrm{m}^{2}\right), \mathrm{W}=$ mean width of the gully and $\mathrm{D}=$ mean depth of the gully

The value of the cross-sectional area obtained was used to estimate the volume of soil removed by gully erosion from each of the study catchments; Bar chart, Table and percentage were used to present results. (One-way ANOVA) was used in testing the hypothesis. Analysis of Variance is one of the statistical tools for investigating difference between means. It allows multivariate 
comparison of mean and calculates the significance of the association for more than one predictor variable at a time.

Grand mean, X

$$
X=\frac{\text { Overall total values }}{\text { Overall total case, }}=\frac{\sum \sum x i j}{N \sum \text { nj }}
$$

Where,

\section{¿xijisthesumofallsamplevaluesandNthenumbersof} devaluesofthesample

\section{Measurement of the Morphometry Character of the} Gullies; Measurement of the gullies were taken at the
a) Gully width
b) Gully depth
c) Cross sectional Area;

The cross-sectional area (CSA) of each of the study gullies was determined using a formula adopted from Oformata [5]

$\mathrm{A}=$ wd... A $=$ Cross sectional area, $\mathrm{w}=$ width and $\mathrm{d}=$ depth

\section{Results}

The frequencies of responses and what they revealed concerning the impact of gully erosion were examined.

Table 1 below shows that the major causes of gully erosion in Eke were rainfall $(40 \%)$, inadequate drainage system $(23.3 \%)$, nature of soil $(20 \%)$ and indiscriminate land use activities $(16.7 \%)$.

Table 1. Distribution of Respondents into Perceived factors causing Gully Erosion in Eke.

\begin{tabular}{|c|c|c|}
\hline Casual factors & $\begin{array}{c}\text { Responses } \\
\text { frequency }\end{array}$ & $\begin{array}{c}\text { Percentage of } \\
\text { responses (\%) }\end{array}$ \\
\hline High rainfall & 60 & 40 \\
\hline $\begin{array}{c}\text { Inadequate and bad } \\
\text { drainage system }\end{array}$ & 35 & 23.3 \\
\hline $\begin{array}{c}\text { Indiscriminate land } \\
\text { use activities }\end{array}$ & 25 & 16.7 \\
\hline Nature of soil & 30 & 20 \\
\hline Total & 150 & 100 \\
\hline
\end{tabular}

Sources: Field work 2014

The Table 2 and Figure 4 below show that the total annual rainfall in the area is generally high. About 90 percent of rainfall is experienced between the months march to October which is mainly responsible for the development of erosion and gully channels on the friable soil of the study area.

Table 2. Mean Monthly and Annual Rainfall of Enugu State

\begin{tabular}{|c|c|c|c|c|c|c|c|c|c|c|c|c|c|}
\hline Year & Jan & Feb & Mar & April & May & June & July & Aug & Sept & Oct & Nov & Dec & Annual total \\
\hline 2004 & 0.6 & 6.4 & 4.8 & 186.8 & 305.5 & 222.5 & 284.1 & 174.1 & 174.1 & 258.1 & 22.1 & 33.1 & 1672.2 \\
\hline 2005 & 0 & 26.9 & 20.8 & 115.6 & 170 & 258.3 & 277.6 & 292 & 283.6 & 228.5 & 24.1 & 19.1 & 1716.5 \\
\hline 2006 & 43.9 & 4.6 & 78.9 & 138.4 & 375 & 369.2 & 402.5 & 188.3 & 261.8 & 233.7 & 0 & 0 & 2096.3 \\
\hline 2007 & 0 & 3.4 & 70 & 33 & 288.4 & 306.7 & 329 & 261.9 & 286.1 & 265.8 & 0 & 0 & 1844.3 \\
\hline 2008 & 12 & 0 & 56.7 & 191,6 & 281.2 & 250.6 & 221.3 & 338.4 & 300.2 & 37.2 & 0 & 0 & 1497.6 \\
\hline 2009 & 50.1 & 0 & 11.1 & 122.4 & 347.1 & 206 & 280.5 & 154.3 & 204.7 & 384.6 & 18.9 & 0 & 1779.7 \\
\hline 2010 & 0 & 0 & 20.2 & 162.8 & 199.3 & 392.5 & 137.6 & 150 & 398.1 & 226 & 1 & 0 & 1687.5 \\
\hline 2011 & 0 & 47.3 & 118.4 & 118.1 & 220.2 & 189.5 & 185.8 & 195.4 & 237.4 & 443.2 & 154.3 & 0 & 1909.6 \\
\hline 2012 & 39 & 21.2 & TR & 129.5 & 288.7 & 282.5 & 388.2 & 312.5 & 693.2 & 213 & 73.9 & 0 & 2441.7 \\
\hline 2013 & 23.4 & 0 & 1.7 & 140 & 296.7 & 382.4 & 211.9 & 326.4 & 430.1 & 113.5 & 8.7 & 97.8 & 2032.6 \\
\hline Total & 169 & 109.2 & 412.6 & 1339.1 & 2.772 .1 & 2860.5 & 2718.5 & 2333.3 & 3269.3 & 2403.6 & 303 & 150 & 16068.1 \\
\hline
\end{tabular}

Sources: (Nimet 2013). 


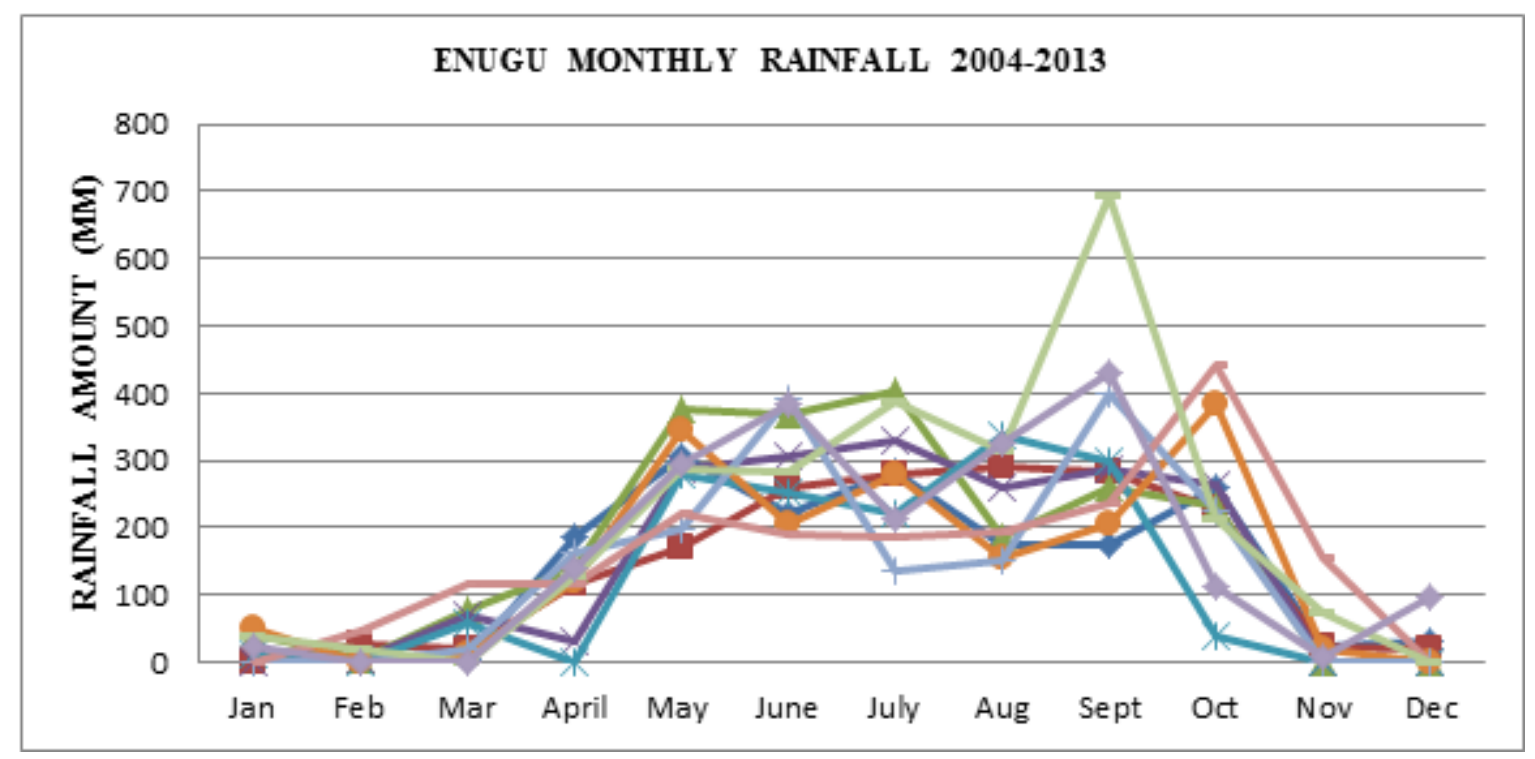

Source: Authors Laboratory.

Figure 4. Enugu Monthly Rainfall 2004-2013

\subsection{Measurement of the Morphometry Character of the Gullies.}

The results of the measurement of the cross sectional areas of the study is shown in table 3 below

Table 3. Measurement of Gully Sites

\begin{tabular}{|c|c|c|c|}
\hline \multicolumn{2}{|c|}{ Gully } & \multicolumn{2}{|c|}{ Dimension } \\
\hline Selected sites & Width $\mathrm{x}^{1}(\mathrm{~m})$ & Depth $\mathrm{x}^{2}(\mathrm{~m})$ & $\mathrm{CSA} \mathrm{x}^{3}(\mathrm{~m})$ \\
\hline Enugu Eke & 2 & 15 & 30 \\
Oma Eke & 3 & 9 & 27 \\
Ogui Eke & 1.5 & 8.5 & 12.8 \\
\hline
\end{tabular}

Source: Field work 2014

As presented in Table 4. The gully in Enugu Eke has a mean cross-sectional dimension of $15.67 \pm 14.01 \mathrm{~m}$, that of Oma Eke has a mean cross-sectional dimension of $13.00 \pm 12.49$, while that of Ogui Eke has a mean cross-sectional dimension of $7.60 \pm 5.70$. From these mean values, differences are observed among the various study sites, however, with very high standard deviations and standard errors for Enugu Eke and Oma Eke, the dimensions of the gullies in the three locations do not really differ that much.

Table 4. Descriptive Statistics of Morphometric Characteristics of Gullies in Different Location

\begin{tabular}{|c|c|c|c|c|c|c|c|c|}
\hline & \multirow{2}{*}{$\mathbf{N}$} & \multirow{2}{*}{ Mean } & \multirow{2}{*}{ Std. Deviation } & \multirow{2}{*}{ Std. Error } & \multicolumn{2}{|c|}{ 95\% Confidence Interval for Mean } & \multirow{2}{*}{ Minimum } & \multirow{2}{*}{ Maximum } \\
\cline { 1 - 4 } & & & & & Lower Bound & Upper Bound & & \\
\hline Enugu Eke & 3 & 15.6667 & 14.01190 & 8.08977 & -19.1408 & 50.4742 & 2.00 & 30.00 \\
\hline Oma Eke & 3 & 13.0000 & 12.49000 & 7.21110 & -18.0269 & 44.0269 & 3.00 & 27.00 \\
\hline Ogui Eke & 3 & 7.6000 & 5.70351 & 3.29292 & -6.5683 & 21.7683 & 1.50 & 12.80 \\
\hline Total & 9 & 12.0889 & 10.43473 & 3.47824 & 4.0680 & 20.1097 & 1.50 & 30.00 \\
\hline
\end{tabular}

ANOVA results are presented in Table 4. Since the calculated F-value of 0.395 , is less than the critical F-value of 5.14, and the p-value of 0.69 at 0.05 significant level, the difference observed among the three study sites is not significant. Hence, the null hypothesis is accepted; showing that there is no significant difference in the mean dimensions of gullies in the selected study sites.

Table 5. ANOVA Result

\begin{tabular}{|c|c|c|c|c|c|}
\hline & Sum of Squares & Df & Mean Square & F & Sig. \\
\hline Between Groups & 101.342 & 2 & 50.671 & .395 & .690 \\
\hline Within Groups & 769.727 & 6 & 128.288 & & \\
\hline Total & 871.069 & 8 & & & \\
\hline
\end{tabular}


Table 6. Distribution of Respondents into perceived Causes of gully erosion in Eke.

\begin{tabular}{|c|c|c|c|}
\hline S/N & Question & No of respondents & Percentage \\
\hline 1 & Weather characteristic & 40 & 40 \\
2 & Land management and agriculture & 25 & 16.7 \\
3 & Development of infrastructure & 35 & 23.3 \\
4 & Soil properties & 30 & 20 \\
\hline & Total & 150 & 100 \\
\hline
\end{tabular}

\subsection{Results on perceived causes of Gully Erosion at the Study Area}

Table 6 shows respondents perception on the causes of gully erosion in the study area are mainly the physical factor (which comprises topography, climate elements especially rainfall and vegetation) and the human factor (mainly activities of road construction, mining, bad method of farming and deforestation).

\section{Weather Characteristic}

The study area witness high intensive and frequent rainfall event with more storms erosion is bound. These storms are common especially during the raining period.

\section{Land Management and Agriculture}

Most of the farmers engaged in crop planting at the study area. They clear and burn down the forest to farm thereby stripping the area of vegetal cover and this makes the soil prone to erosion. At Ogui Eke, human activities are great causative agents of erosion. Deforestation exposes the bare soil for denudation and elevation. Poor land use and management destroy the soil fertility and exposes it to erosion.

\section{Development of Infrastructures}

The case of construction works at the study area is another major factor that gave chance for actives erosion. Most soil protective tree and secondary vegetation were destroyed during construction which has greater impact on the soil thereby exposing natural soil to have which is easily eroded.

\section{Soil Properties}

The soil at Enugu Eke is porous with soil texture. This allows excessive infiltration of rain water. At saturation the runoff water detaches the particles of the frail and cohesion less soil, transporting them downward. The soil of the study areas is highly weathered, leached and contained comparatively smaller amount of tumus which could have helped to bind the soil particles together. Some parts consist of clay which is rather prone to soil creep and landslide.
Table 7 below shows that in Ogui Eke community, 70 questionnaires constituting that $35.00 \%$ of the total questionnaires were administered and 51 questionnaires constituting $34.00 \%$ were returned, 70 questionnaires constituting $35.00 \%$ were administered to Enugu Eke community and 50 questionnaires constituting $33.33 \%$ were returned and 60 questionnaires constituting 30.00\% were administered to Oma Eke and 49 questionnaires constituting $32.66 \%$ were returned. A total of 150 copies of questionnaires were returned out of the 200 copies of questionnaires administered. The number returned were those that was filled correctly and returned. Ogui Eke and Enugu Eke have the highest numbers of questionnaires because of its population. Since the questionnaires were administered in proportion to the population of the communities.

Table 7. Total Number of Questionnaires Distributed to Residents in Different Communities

\begin{tabular}{|c|c|c|c|}
\hline Communities & $\begin{array}{c}\text { Number } \\
\text { Distributed }\end{array}$ & $\begin{array}{c}\text { Number } \\
\text { Returned }\end{array}$ & Percentage \\
\hline Enugu Eke & 70 & 50 & $33.33 \%$ \\
Oma Eke & 60 & 49 & $32.66 \%$ \\
Ogui Eke & 70 & 51 & $34.00 \%$ \\
\hline Total & 200 & 150 & $100 \%$ \\
\hline
\end{tabular}

Source: Field work, 2014.

\subsection{Results as to perceived Impact of Gully Erosion to the people of the Study Area}

\subsubsection{Building Foundations}

Observations from the field show (Figure 5 and 6) that the buildings in the study area have been washed away by the gully erosion and have been abandoned because of gully erosion. The information gathered from field observation and literature shows that the soil at Eke is made up of clay and sandy soil. This type soil is prone to gully erosion, thereby affecting the foundations of those houses which later introduce cracks on the walls of the buildings. 


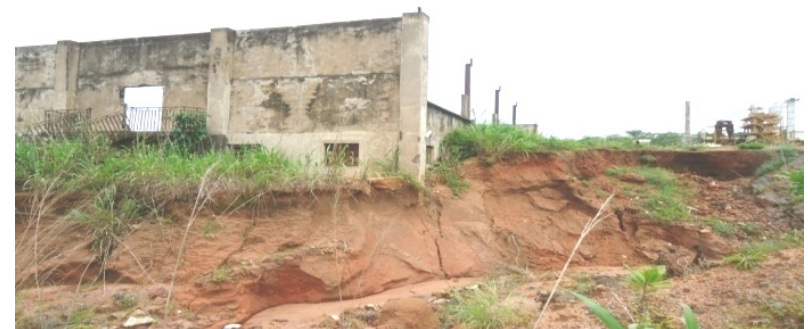

Figure 5. The Effect of Gully Erosion on a Building at Eke

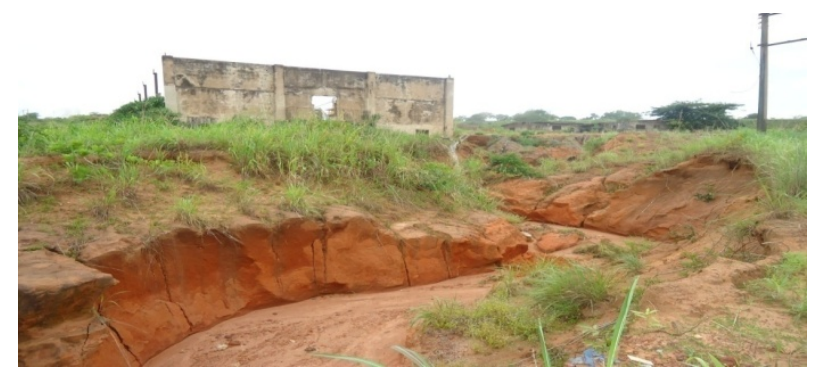

Figure 6. The Effect of Gully Erosion on a Building at Eke

\subsubsection{Impact of Gully Erosion on the Infrastructure}

Field observations below further showed (Figure 7-9) that roads, water and electricity facilities have been affected in different ways by the menace of gully erosion. The road linking Enugu Eke and Ogui Eke has become a death trap, and has separated the two communities. The electric poles have been pulled out by gully erosion, causing black out to some communities, also the water facility at Oma Eke was also affected due to the frequent runoff, which caused flooding in the area.

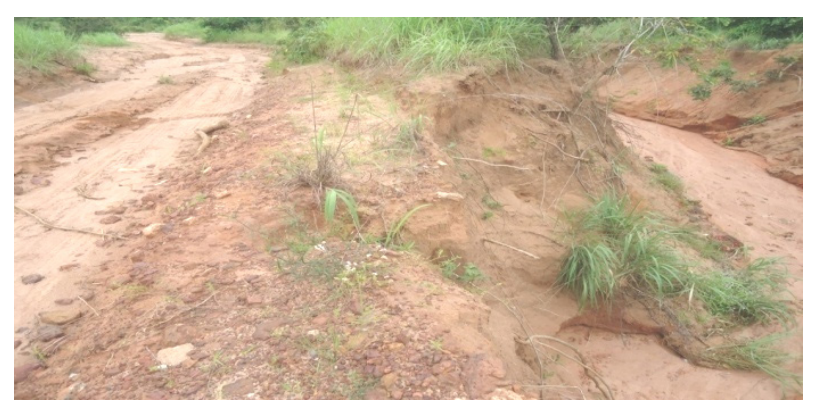

Figure 7. Effect of Gully Erosion on the Road at Eke

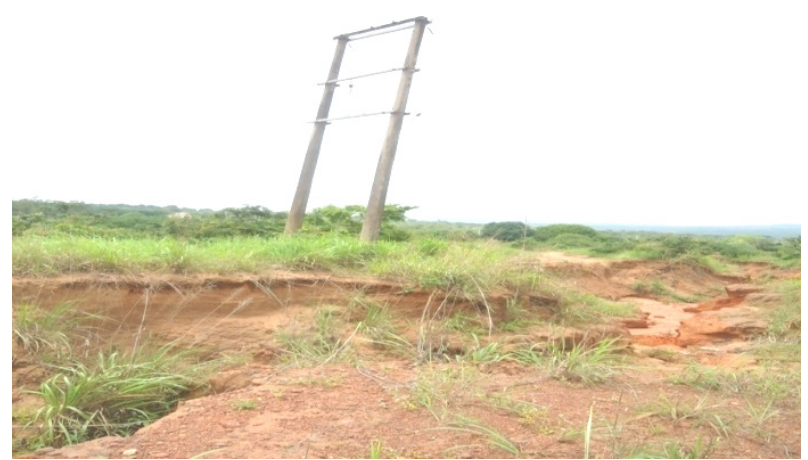

Figure 8. Effect of Gully Erosion on Electric Pole at Enugu Eke

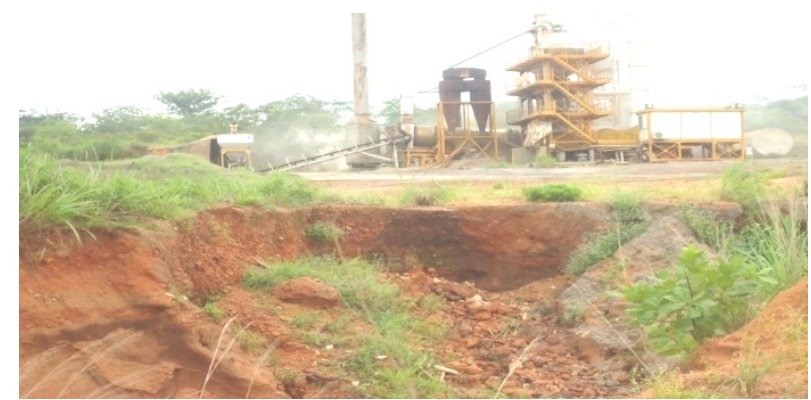

Figure 9. Effect of Gully Erosion on Road at Enugu Eke

\subsection{Impact of Gully Erosion on Agriculture}

Field observations (figure 10) further shows that there is a general decrease of soil fertility as the erosion deplete the top soil of vital plants nutrients. The continual expansion of the gullies leads to the demotion of cultivable land, which leads to repeated cultivation of the available lands without fallowing which results in low yield. Also the existence of gully erosion in these study area influence location of farm, type of crops to plant. This menace decreased the available lands, causing scramble for the few available space.

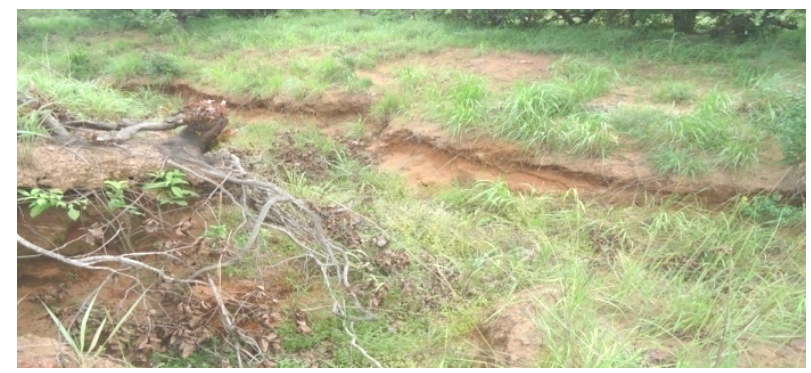

Figure 10. Effect of Gully Erosion on Farm Land at Oma Eke

Table 8 below shows distribution of respondents perceived effects of gully erosion in the study area. The table indicates that the major effects of soil erosion in Eke, was loss of soil fertility $(26.7 \%)$, seconded by loss of lives and properties, with respondents of $(23.3 \%)$ followed by water facilities with respondents of $(20 \%)$.destruction of routes ways/roads, with respondents of (16.7\%) while the least is Indiscriminate of cultivable land (13.3).

Table 8. Distribution of Respondents into Perceived Effects of erosion in Eke

\begin{tabular}{|c|c|c|}
\hline Options & $\begin{array}{c}\text { No of } \\
\text { respondents }\end{array}$ & Percentage \\
\hline Loss of lives and properties & 35 & $23.3 \%$ \\
Destruction of route ways /roads & 25 & $16.7 \%$ \\
Destruction of water facility & 30 & 20 \\
Loss of soil fertility & 40 & $26.7 \%$ \\
Diminution of cultivable land & 20 & 13.3 \\
\hline Total & 150 & $100 \%$ \\
\hline
\end{tabular}

Source: Field work, 2014

\subsection{Gully Erosion control at the Study}

Table 9 shows distribution of respondents into perceived control measures of gully erosion in the study area. The 
table indicate that 50 respondents $(33.3 \%)$ of the population suggested the planting of vegetative cover as best gully erosion control measure, whereas 40 respondent $(26.7 \%)$ suggested the construction of erosion channel is better, while 40 respondent (26.7) believes in Agricultural method of erosion control.12 respondents $(8 \%)$ agree with the idea of minor impoundment, lastly 8 respondent $(5.3 \%)$ believes that combining all the methods is better.

Table 9. Distribution of Respondents into Perceived Control of erosion in Eke.

\begin{tabular}{|c|c|c|}
\hline Options & $\begin{array}{c}\text { No of } \\
\text { respondents }\end{array}$ & Percentage \\
\hline Construction of erosion channel & 40 & $26.7 \%$ \\
Planting of vegetation & 50 & $33.3 \%$ \\
Agricultural method control & 40 & $26.7 \%$ \\
Creation of awareness & 12 & $8 \%$ \\
All of above & 8 & $5.3 \%$ \\
\hline Total & 150 & $100 \%$ \\
\hline
\end{tabular}

Source: field work, 2014

\subsubsection{Biological Measures}

The people residing at these gullies areas uses biological practices in controlling gully erosion in the study area. They practices mulching, terrace farming and makes ridges when cultivating. In addition to aforestation (Figure 11), reforestation for soil protection, economic trees are also planted for gully erosion control at the study area.

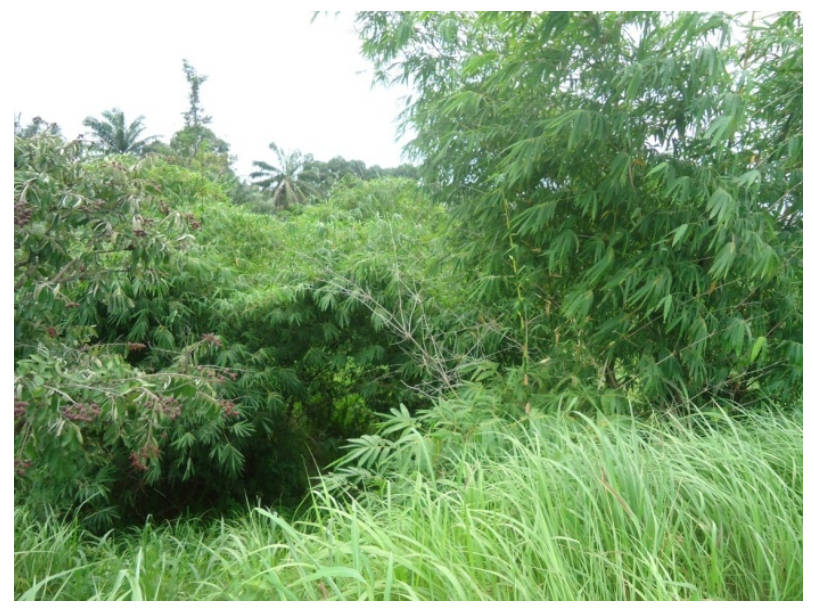

Figure 11. Early Aforestation for Soil Restoration by the use of Bamboo Tree to Check Erosion

\subsubsection{Engineering Measures}

Engineering structure were introduced by the Government and the people at the these study areas by constructing concrete diversion channel in order to help reduce the velocity of runoff or direct channel flood or water from waste that have been destructive. Governments have also helped in making laws that protect the environment. For an example at Eke Ugwu, government mounted sign post with inscription no sand mining, No stone mining, no gravel mining and no cattle rearing (Figure 12) in order to protect the environment at Eke.

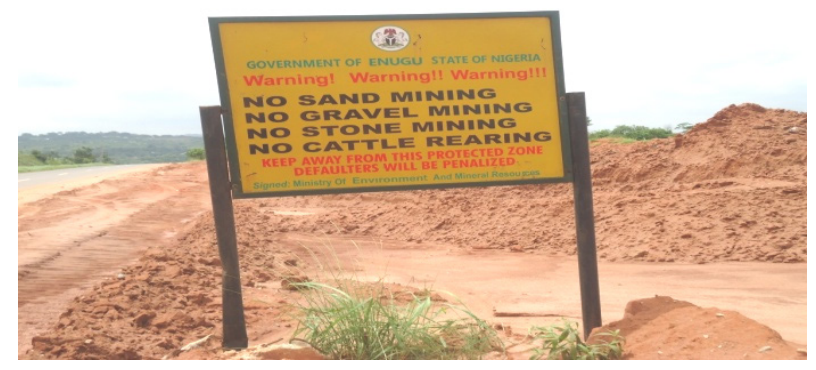

Figure 12. Government Measures of Controlling Gully Erosion at Eke Ugwu

\section{Discussion of Result}

The major type of soil erosion affecting the Eke in Udi L.G.A is mostly gully erosion, this is in line with earlier observation by Ofomata, G.E.K in his work in [5] discussing Soils and Soil Erosion; A Survey of the Igbo nation. The study revealed that the initiation and development of erosion gullies facilitated by natural processes (rainfall, topography, geological properties of soil especially texture, etc.) and the activities of man, especially road construction, excavation, drainage structure, farming and animal grazing, this finding is also in line with Igwe, C. A [8] work on Gully Erosion in Southeastern Nigeria, where noted the role Soil Properties and Environmental Factor play in soil erosion menace in South East, Nigeria.

Further still the study found out that the reduction of soil fertility is also at the higher side causing low agriculture productivity in the area and as such contributes to the migration of the people from the area to a more conducive area for agricultural activities and employment opportunities this is also in line with Okwu-Delunzu V.U et al [9], in their work of Monitoring Gully Erosion at Nyaba River of Enugu State Southeastern Nigeria, the finding show that most people who engage in agricultural activity at the river corridor, that gully erosion has degraded their farm lands. The study also identified the impacts of these gully erosion on the socio economic livelihood of the people, that gully erosion caused the disruption of communication routes/roads and loss of landed properties in Eke. The study also reviled that properties worth million naira were lost, this finding is true also as noted by Okwu-Delunzu V.U [14] in his research work title Runoff Assessment of Soil Erosion-Induced Landform Degradation in Nyaba River Basin south east Nigeria.

It was substantially identified in this study that the gully erosion parameters which include the height, width, depth and duration do not have significant difference in the mean dimension of gullies in the selected study sites. The gully erosion parameters were tested in hypothesis one of this study. This is supported by the ANOVA results presented in Table 4.5. Having a calculated F-value of 0.395, which is less than the critical F-value of 5.14, and the p-value of 
$0.69>0.05$ at 0.05 confidence level, the difference observed among the three study sites, is not significant. Hence, the null hypothesis is accepted. Therefore, there is no significant difference in the mean dimensions of gullies in the selected study sites.

The study revealed that Government of Enugu state was never in any way exhibited neglect among the affected areas. Numerous structural and nonstructural measures were taking in due consideration to rescue the internal displaced person (IDP) through State Emergency and Management Agency (SEMA) and their Federal counterparts NEMA and other government agencies. It was also observed that Nigeria Meteorological Agency (NIMET) played substantial roles in predicting the seasonal rainfall on monthly and annual basis. None Governmental Agencies, church members and numerous compassionate friends also aided in their own substantial ways (NIMET [13]).

However measures like planting of vegetative cover, construction of Erosion channels, Agricultural method control and creation of awareness can be applied to control this menace.

\section{Conclusions}

Soil erosion in the form of gullies is very common in most places in South east Nigeria especially in Eke. This study has shown the influence of geology, climate, geomorphology (slope), vegetation, development and soil erosion in general. Empirical examples are cited from previous works of other researchers, which estimated of potential soil erosion hazards in the region at about $1.6 \%$ of the entire land area. The inherent characteristics of Eke soil to a large extent promote the spread of soil erosion especially the gully type. The roles of anthropogenic factors with regards to land use and its influence on the vegetation are highlighted. The serious deforestation of the vegetation and poor revegetation or afforestaion programmes have all contributed to the catastrophic erosion hazards. General strategies for soil conservation with respect to soil erosion should include a more comprehensive soil conservation method which will involve the application of certain hydrological or bioenvironmental processes so as to control the overland flow and excessive runoff.

The most serious, environmental problem in Eke area is gully erosion. The erosion menace in Eke has caused severe destruction of the soil and reducing the cultivable land. Moreover destruction, of route ways and roads, loss of lives and properties as well as were established as serious effects of the gully erosion. Control measures have been suggested. These are classified under:

a) Management of the physical environment, (The use of agricultural methods and system and administrative approach).
The study recommends that Communities should engage in more public awareness initiatives and put in place structures that can govern and implement best land practices. Effective land management practices coupled with pragmatic public awareness measures within the community is crucial to mitigate further onset of gully erosion in the region including:

a) Enhanced aforestation, prevention of bush burning and overgrazing would reduce gully erosion.

b) The Federal ministry of environment together with local communities should design public awareness programme on the causes and mitigation measures of gully erosion.

c) Organization and churches should be more involved in public awareness measures and capacity building programmes such as planting of grasses on available favourable surface, aforestation project in the areas more susceptible to gully formation and planting of local cover crops.

d) Use of geographical information satellite system could help in mapping and managements of gully erosion affected areas.

\section{REFERENCES}

[1] Morgan, R. P. C. Soil Erosion and Conservation. John Wiley and Sons Publishers; 2005.

[2] Ofomata G.E.K. Soil Erosion characteristics, processing and extent in the lowland forest rain forest area of southeastern Nigeria. In Sagua V.O, Enabor E.E.; 1988.

[3] Strahler, A.N. Physical Geography (4th edition) New York; John Willy \& Sons inc. 1975.

[4] Siakeu, J. and Oguchi. T .Soil erosion analysis and modeling: A review. Transactions of the Japanese Geomorphological Union 21(4); Pp 413-429. Soil Science Society of America: Glossary of Soil Science Terms. Soil science Society of America, Madison, WI, 2000) http:/www.soils.org/sssagloss/. 2001

[5] Ofomata, G.E.K: Soils and Soil Erosion. In: Ofomata, G.E.K (Ed). A Survey of the Igbo nation. African first publishers Ltd 2002.

[6] Ajaero, C.K. and Mozie, A.T. The Agulu- Nanka Gully Erosio Menace: What does the future hold for the population at risk? In: Michelle Leighton, Xiaomeng Shen and Koko Warner (Eds)(2011):Climate Change and Mitigation: Rethinking policies for Adaptation and Disaster Risk Reduction. Publication series of UNU-EHS NO. 15/2011, UNU-EHS, Bonn. Germany; 2011. Pp 1-22

[7] Enugu State Ministry of Environment Field Survey, (2010), Report Booklet

[8] Igwe, C.A. Gully Erosion in Southeastern Nigeria: Role of Soil Properties and Environmental Factors. Department of Soil Science, University of Nigeria, Nsukka. Nigeria.2012

[9] Okwu-Delunzu V.U et al: Monitoring Gully Erosion at 
Nyaba River of Enugu State Southeastern Nigeria, Using Remote Sensing: SPIE Proceeding Volume 8887. Doi:10.1117/12.20359672013

$\mathrm{http} / /$ proceedings.spiedigitallibrary.org/proceeding.aspx?ar ticleid $=1757301$

[10] Igbokwe, J.I., Akinyede, J.O., Dang, B., Alaga, T., Ono, M.N., Nnodu, V.C., and Anike, L.O Mapping and Monitoring of the Impact of Gully Erosion In Southeastern Nigeria with Satellite Remote Sensing and Geographic Information System. International Archives of Photogrammetry, Remote Sensing, and Spatial Information Sciences, vol. XXXVII, part B8, Beijing; Pp 865-871 2008.

[11] Okwu-Delunzu V.U (2014). Runoff Assessment Of Soil Erosion-Induced Landform Degradation In Nyaba River
Basin, Enugu State of Southeastern Nigeria Unpublished $\mathrm{PhD}$ Thesis; Federal University of Technology, Minna Niger State. Nigeria

[12] NPC (National Population Commission) (2006) Census Review Pp 3.

[13] Nigerian Meteorological Agency (NiMET)(2014); Seasonal Rainfall Prediction March 2014 Pp 38-42

[14] Mozie, A.T (2010): Some Observation on the Causative factors and slide Processes in the Ududonka Gully head, Isiama Igbo, Agulu, Naocha L.G.A, Anambra. State. Paper presented at the International Conference on slides and National Hazards organized by the Geology Department, UNN, and the Landslide Institute, Kyoto, Japan, March, $2-26,2010$ 